Studia Anglica Posnaniensia 45/1, 2009

(C) School of English, Adam Mickiewicz University, Poznań, Poland

doi: 10.2478/v10121-009-0003-8

\title{
RECONSIDERING THE ROLE OF SYNTACTIC "HEAVINESS" IN OLD ENGLISH SPLIT COORDINATION
}

\author{
RODRIGO PÉREZ LORIDO
}

University of Oviedo

\begin{abstract}
The splitting of coordinate structures in Old English has traditionally been attributed to structural size or "heaviness", assuming that long, complex coordinate constructions required increased parsing and processing effort. In addition to this, most texts on Old English syntax take for granted that the split elements always appear in clause-final position. The conclusions in this paper - drawn from the analysis of a large corpus of Old English texts - imply a radical revision of these assumptions. They suggest that the role of syntactic heaviness should be reconsidered, and its importance minimised in favour of other considerations of a pragmatic and discoursive nature. The analysis of the position of the split elements confirms that they appear in non-final position much more often than has been assumed, producing syntactic discontinuity.
\end{abstract}

\section{Introduction}

Split coordination (illustrated in 1a-c below) is considered as one of the most characteristic features of Old English syntax, along with discontinuous constructions in general. In spite of this, it can be said that no successful account of the phenomenon has been produced to the present date, and that a number of central questions regarding its nature and grammatical status remain unsolved.

1a) Her Beorhtric cyning forpferde \& Worr aldormon.

'In this year king Beorhtric passed away, and ealdorman Worr'

(ChronA 800.58).

b) Se ðe god lufað \& men he hylt ealle godes bec.

'He who loves God and men, he remains faithful to the book of all good' 
c) ... gif mon on niwne weall (...) micelne hrof \& hefigne onset ... ' ... if a big, heavy roof (...) is placed on a new wall ...

Some of these questions are:

i. What causes coordinate structures to split up in Old English?

ii. What is the position of the split elements?

Past studies of Old English syntax have rarely addressed these issues, as no large-scale corpus-based analysis study of the construction has been carried out to the present date. Considering that split coordination in Old English has not even been adequately described, the first aim of this study is to clarify some facts concerning the data, from where I will proceed to investigate the grammatical aspects that revolve around split coordination in Old English, analysing it from different linguistic perspectives such as syntax, discourse and information processing, in the hope of providing an answer to some of the questions mentioned before.

\section{Method and materials}

The method I have used in this paper consists of analysing all the instances of split subjects in a large corpus of Old English prose, as well as all the examples of unsplit coordinated subjects in the same contexts. ${ }^{1}$ I think a comparison of both structures is more likely to reveal the underlying factors that govern split coordination than analysing examples of splitting alone, which has usually been the case in the literature. Lacking essential prosodic information (intonation, stress), which might provide crucial answers to many of the questions posed here, I have focused on the textual material, checking the relevant examples against different linguistic variables, carrying out statistical measurements of the data, and analysing the results in the light of recent linguistic theory.

The corpus consists of eight complete texts from the early and late Old English periods, arranged chronologically: ${ }^{2}$

Early Old English: Pastoral Care (CP); Orosius (Or); Boethius (Boeth), Bede

1 For practical reasons I have limited the scope of this study to split subjects only, even though split coordination is a very pervasive phenomenon which applied virtually to any syntactic category in Old English. My work in progress involves the study of split objects, verbs and NP modifiers too.

2 See the references for details on the texts and editions used. 
(Bede); Parker chronicle (ChronA).

Late Old English: Peterborough chronicle (ChronE); Ælfric's Catholic homilies - second series (AECHom ii); Ælfric's Lives of saints [volume I only] (ALLS 1); Wulfstan's Homilies (WHom).

These amount to roughly 1.700 pages of text and constitute a quite representative sample of the different types of English prose (annalistic, narrative, argumentative) from the $9^{\text {th }}$ to the $11^{\text {th }}$ centuries. The relevant data stem essentially from my own reading of the texts. ${ }^{3}$

\section{Analysis}

\subsection{The causes of split coordination}

We can isolate three major views on the causes of split coordination in general:

I. Structural complexity ("size", "heaviness..."): Split elements would be moved to the right simply as an application of the principle of end-weight (Behaghel 1909), as the accumulation of complex elements to the left of the sentence would cause processing and perceptual problems (Hawkins $(1990,1994)$.

II. Focus, emphasis: The split element would be considered a communicatively salient one, and therefore detaching it from the initial conjunct and moving it towards the right of the sentence would be a way of highlighting it.

III. Afterthought. Split elements would be considered as late additions in the process of production of an utterance, which were not in the original plan. ${ }^{4}$

As far as Old English is concerned, a long-standing tradition (Reszkiewicz 1966; Traugott 1972: 97; Kohonen 1978: 185; Mitchell - Robinson 1986: 67) maintains that split coordination is caused by syntactic complexity ("heaviness"), assuming that Old English speakers found long, complex, structures (including coordinate ones) difficult to process, and therefore proceeded to break them into smaller pieces, placing some part of them to the right of the

3 Using a computerised tagged corpus like the York corpus of Old English (Taylor et al. 2003) would undoubtedly have made my data collection a much less hard and time-consuming job, but unfortunately the York corpus was still not available when I started gathering my examples on coordination in Old English. I have used it at times to confirm my own material.

4 Though this is possibly a standard definition of "afterthought", I do not think it is the best one to explain the Old English facts, as I will show in the following sections. 
clause. Under this perspective, split coordination would not be different from other right-extraposition phenomena such as Heavy-NP Shift or Relative Extraposition, which are said to respond to the same tendency. ${ }^{5}$ This view has remained to a great extent unchallenged to the present day, in spite of the very thin empirical support it has, and even very recent texts on Old English syntax and web pages offering introductory courses on Old English syntax present this view as a matter of fact. ${ }^{6}$ In what follows I will try to prove that "heaviness" (whatever its definition), is not a crucial factor in Old English split coordination

\subsubsection{Heaviness}

The notion "heaviness" or "weight" is a very controversial one, and finding an adequate definition of it has received a good deal of scholarly attention in the last few years. Ferreira (1991), Hawkins (1994), Rickford et al. (1995), Wasow (1997), Arnold et al. (2000), Mondorf (2003), to name only a few, have analysed and discussed the concept "weight" or "size" from many different perspectives and theoretical stances. From these studies two basic measures of syntactic weight arise: length and complexity.

i. Length (number of words). Syntactic weight is measured as the difference in the number of words between constituents (Hawkins 1990; Arnold et al. 2000).

ii. Complexity (internal constituent architecture). The number of nodes, including phrasal nodes, determines the syntactic size of a given syntactic structure (Ferreira 1991), Hawkins (1994), Rickford et al. (1995).

The results of the corpus analysis reveal that - whichever of the two criteria to define heaviness we opt for - split coordination in Old English does not seem to depend crucially on it:

\section{Criterion $\mathrm{n}^{\mathrm{o}}$ 1: Length}

Heavy subjects (in terms of number of words) subjects do abound in the corpus. The following examples, despite having fairly simple internal structures, are

5 Postposition of heavy arguments has been traditionally claimed as the fundamental cause for the reanalysis SOV $\rightarrow$ SVO in the history of English. See Canale (1976), Stockwell (1977), Kamenade (1987), Colman (1988), Pintzuk and Kroch (1989).

6 For example: http://www.arts.gla.ac.uk/SESLL/EngLang/ugrad/OE/SentenceStructure3Plus. html (accessed 25 June 2007). 
indisputably long:

2a) Iulianus ba and se geonga cniht martianus sunu and his moder samod, Antonius se preost and se ge-edcucode man wurdon to-somne ofslagene for Criste. $^{7}$

'Julianus then and the young knight, Martianus' son, and his mother also, Antonius the priest, and the resuscitated man, were all slain together for Christ's sake'

( $E L S$ 1.114.410).

b) 845. Her Earnulf dux mid Sumorsceton \& Ealchstan $b \&$ Osric Dux mid Dorsceton gefuhton æt Pedredan mupan wið Deniscne here.

'845. In this year ealdorman Earnwulf with the men of Somerset and bishop Ealhstan and ealdorman Osric with the men of Dorset fought against a Danish host at the mouth of the Parret'

(ChronE 845.65).

c) Pa Pompeius \& Cato \& Ealle pa senatus pæt hierdon, pa ...

'When Pompeius and Cato and all the members of the senate had heard that, then ...' (Or 126.22)

In addition to this, and contrary to the "heaviness" hypothesis, splitting of very short and structurally simple coordinate subjects is very frequent in the corpus:

3a) $\mathrm{p}$ is, $\mathrm{p}$ englas habbath \& wise men.

'That is, what angels and wise man have'

(Boeth 254.4).

b) 687. Her Mul wearp on Cent forbærned, and opre xii men mid him.

'687. In this year Mul was burned to death in Kent and twelve other men with him' (ChronA 687.38)

c) Drihten ba astah into pam scipe \& petrus samod.

'Our Lord then ascended into the ship, and Peter too'

(AECHom ii 223.77).

To confirm what the examples above suggest, I have counted the number of words in both split and unsplit NP subjects in all the texts in the corpus, to de-

7 Henceforth, all the coordinate elements under discussion - whether split or unsplit - are in italics. 
termine the average length of each (Table 1$):^{8}$

Table 1. Average length of coordinate NP subjects in both split and non-split structures

\begin{tabular}{lc}
\hline & average number of words \\
\hline Split subject & 5.4 \\
Non-split subject & 4.8 \\
\hline
\end{tabular}

As we can see, the overall difference in average length is obviously too small to be of any significance to the application of the rule, as split and unsplit subjects in the corpus are roughly the same length.

\section{Criterion $n^{\circ}$ 2: Complexity}

Below is a series of examples of long, coordinated NP subjects, in order of increasing complexity. They range from instances in which the internal constituent structure (in terms of number of nodes involved) of the coordinated subjects is fairly simple $(4 a, b)$, to examples where we find subjects with very complex internal structures, including embedded $4 \mathrm{c}$ and even doubly-embedded $4 \mathrm{~d}$ subordinate clauses:

4a) ... pæt poes gefeohtes hream and ðcera deofla gehyld mihte beon gehyred geond ealle eorðan.

'... that the noise of the battle and the combat of the devils could be heard all over the earth'

(AECHom ii 192.72).

b) ... py geare pe seo wildeorlice arleasnis Bretta cyninges \& seo awegoncernis from Cristes geleafan Ongelcyninga onscuniendlic wæs.

' $\ldots$ in the year when the savage impiety of the king of the Britons and the apostasy of the English kings from Christ's faith was detestable'

(Bede 176.23).

8 While I hale counted the words for all the examples of split subjects, only a certain number of pages have been examined for unsplit subjects. Specifically, only the first 40 instances of unsplit coordinated subjects in each text in the corpus have been analysed, but I think this is significant enough. I have not included in the word-count in either case the coordinating conjunction and nor the adverbial expressions samod, eac, or mid him, hire... that often co-occur in the second part of the split coordinate subjects. In those (few) examples in which the coordinate split portion consists of more than one element, all the elements have been counted, except in those cases in which they are a list (usually of proper names) without virtually any internal structure. 
c) Pæt teoðe wæs pæt ealle ða cnihtas \& ealle ða moedena pe on poem lande frumcennede woron wurdon on anre niht acwealde.

'The tenth was that all the boys and all the girls who had been the firstborn would be killed on one night'

(Or 26.5).

d) ... p pa mine scelpa \& seo orsorgnes de ic ar wende $p$ gesepa beon sceoldan nane sælpa ne sint.

'that those my felicities and the prosperity which I formerly thought should be happiness, are no happiness'

(Boeth 26.25).

There is no dearth of examples like these in the corpus. This, together with the evidence provided above, may well lead us to conclude that heaviness - whether defined as internal complexity or as length - was possibly not the most important conditioning factor in the splitting of coordinate structures in Old English.

One further piece of evidence I would like to put forward against a grammatically-based weight-centered explanation of split coordination in Old English is the distribution and relative incidence of the phenomenon in the different texts in the corpus. If split coordination were - as Reszkiewicz (1966: 325) suggests - "... a basically linguistic, structural fact" and responded only to restrictions on the structural size of constituents, we should expect a more or less even distribution of the incidence of split coordination across the corpus. Contrary to expectations, the analysis reveals a rather uneven pattern:

Table 2. Incidence of split subjects proportional to total number of coordinate subjects (excluding coordinate subjects $\mathrm{S}^{\mathrm{n}}$ in sentence-final position) ${ }^{9}$

\begin{tabular}{lcccc}
\hline & Unsplit S & Split S & $\begin{array}{c}\text { Total } \\
\text { coordinate S }\end{array}$ & \% Split S \\
\hline CP & 33 & 0 & 33 & 0 \\
Or & 62 & 17 & 79 & 21.5 \\
Boeth & 84 & 9 & 93 & 9.6 \\
Bede & 87 & 6 & 93 & 6.4 \\
ChronA,E & 170 & 65 & 235 & 27.6 \\
& MS A 57 & MS A 20 & MS A 77 & MS A 25.9 \\
& MA E 113 & MA E 45 & MS E 158 & MS E 28.4 \\
AELS (I) & 51 & 23 & 74 & 31 \\
& \multicolumn{2}{c}{$\mathrm{S}^{\mathrm{n}}$ stands for "unsplit coordinate subject". } & &
\end{tabular}




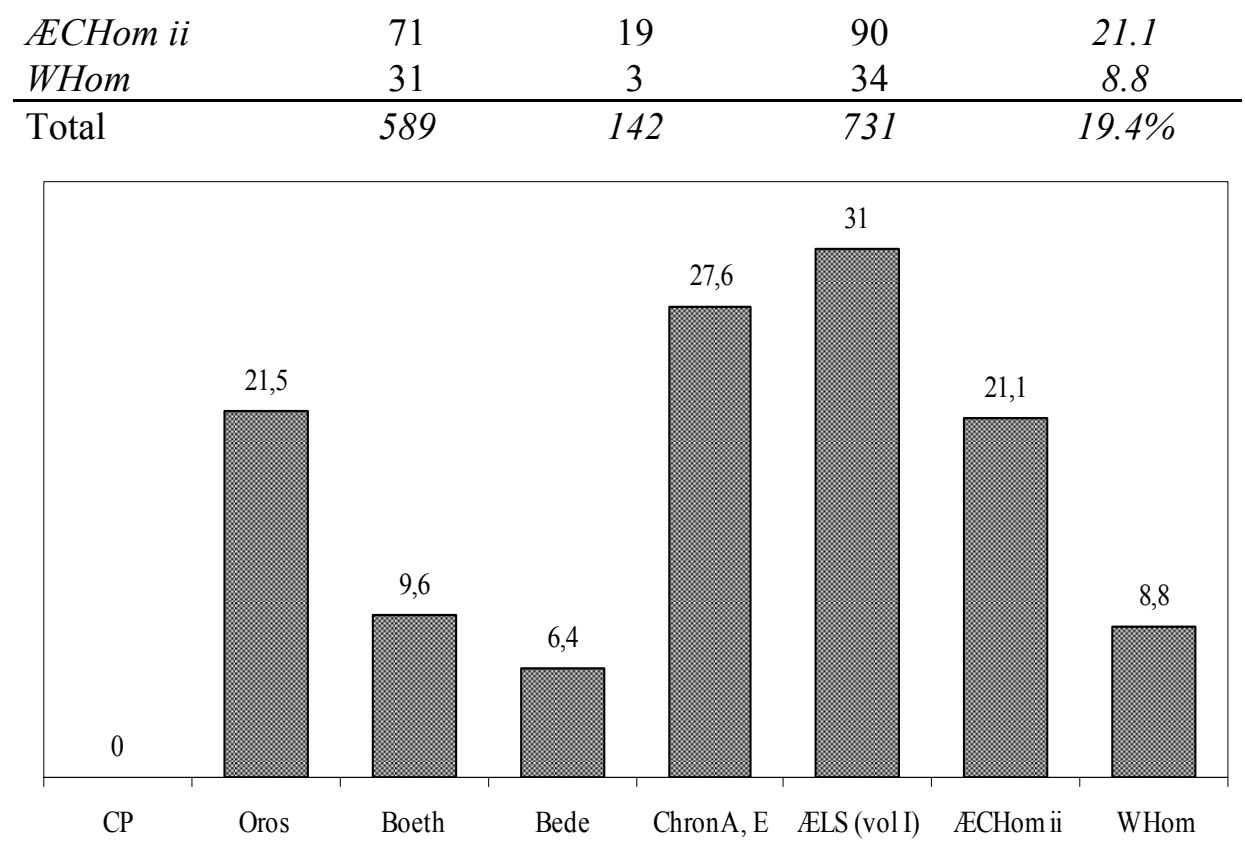

Figure 1. Incidence of split subjects in the corpus

The overall incidence of split subjects in the corpus is nearly $20 \%$, but whereas in some works the incidence is moderately high (around 30\% in the Anglo-Saxon chronicle and Ælfric's Lives of saints), in others it is considerably lower (around $10 \%$ in Boethius and WHom) or even zero (Cura Pastoralis). The date of composition does not seem to be a determining factor in the incidence of split coordination as there is no significant progression over time. It is also clear that some text types favour it more than others. Narrative texts (annalistic ones and Ælfric's works) show a clearer preference for split coordination than texts of a descriptive or argumentative nature such as the Boethius or the Cura Pastoralis. ${ }^{10}$

Having discarded purely syntactic motivations ("heaviness") as the central cause of split coordination in Old English, we will discuss now the possibility that it is triggered by non-syntactic factors.

\subsubsection{Focus}

Transformational studies have dealt with split coordination (stripping in TG terms)

10 Bede is now considered as perhaps the Old English text in which the influence of Latin is greatest (Fischer et al. 2000: 31), so - if we take split coordination to be a typical feature of Old English syntax - the low incidence in Bede does not come as a real surprise. 
but have not explicitly addressed the question of the discoursive status of the split elements. Most of these studies assume - however - that split elements are somewhat emphatic, by considering split coordination as essentially the same rule as gapping (Jackendoff 1971: 26; Hankamer - Sag 1976: 409; Chao 1987: 2; Lobeck 1995: 27-28; Johannessen 1998: 222). According to these authors, in gapping structures like 5 below the elements left after verbal deletion (remnants) are always contrastive with the corresponding phrases in the preceding conjunct, and are therefore in focus in the second sentence. This is clearly shown by the presence of pitch accent (a characteristic of focused elements) on each gapping remnant:

5) Sally ate the Sandwich and MAry Ø the HAmburger.

In split coordination in present-day English -6 below - the contrastive role of the split element(s) is reinforced by the obligatory presence of an additive adjunct or focal adverbial expression like too, also, or as well (Goodall 1987: 28-29), (van Oirsouw 1987: 67). This, at the same time, ensures the necessary conditions on structural parallelism between both parts of the coordinated construction for verbal ellipsis to apply.

6) Sally ate the sandwich, and Mary too.

* Sally ate the sandwich, and Mary.

In Old English split coordination, however, the presence of additive adjuncts like eac (swa), (eac) swilce, samod, or mid him is not obligatory, and quite often the split element appears in isolation in the second, coordinate clause. (See example $3 \mathrm{a}$ above and the table below):

Table 3. Presence of additive adjuncts in split subjects in the corpus

\begin{tabular}{lcccc}
\hline & $\begin{array}{c}\text { Total split S } \\
\text { instances }\end{array}$ & $\begin{array}{c}\text { Presence of additive } \\
\text { adjunct }\end{array}$ & $\begin{array}{c}\text { \% presence additive } \\
\text { adjunct }\end{array}$ & \\
\hline Bede & 6 & 1 & 16.6 & \\
Boeth & 9 & 3 & 33.3 & EOE 35\% \\
Or & 17 & 7 & 41.1 & \\
ChronA,E & 65 & 23 & 35.3 & \\
\hline ELS $(I)$ & 23 & 12 & 52.1 & \\
AECHom $i i$ & 19 & 8 & 47.3 & LOE 46\% \\
Wulfstan & 3 & 1 & 33.3 & \\
\hline Total & 142 & 56 & 39.4 & \\
\hline
\end{tabular}

As we can see, additive adjuncts occur in just around $40 \%$ of the relevant examples in the corpus, but there is an increase in their use over time (from $35 \%$ in 
early Old English to $46 \%$ in late Old English). ${ }^{11}$ This might be an indicator of the progressive move from pragmatic word order to syntactic word order in the history of English (van Hoorick 1994: 76), and more recently (van Kemenade and Los 2006), as a need for parallelism in coordinate elliptical structures seems to be a characteristic of more syntacticised languages (Pérez Lorido 1996).

In addition to this, in present day English split coordination, the split elements appear always in sentence-final position (a position very likely to receive prosodic focal attention), but this is not always the case in Old English, as we will see in section 3.2 .

From these differences between split coordination in Old English and present day English we may have the feeling that split elements in Old English do not necessarily have the emphatic quality they have in present day English and that modern interpretations of split coordination may not necessarily hold for Old English. Unfortunately, very few attempts at analysing the discourse status of split coordination in Old English have been made to date, perhaps with the exception of Mitchell (1985) and Reszkiewicz (1966).

In his monumental work, Mitchell is hesitant about what role to assign to split coordination in Old English. For a long part of his analysis ( $\$ 1464-1472)$ he seems to play with the traditional idea of structural heaviness as being the ultimate cause of the splitting of coordinate structures, but in the closing section ( $\$ 1472)$ he is hesitant and concludes that "... there seems to have been a dislike of 'heavy' groups and perhaps in the early stages even an inability to handle them... but in view of the variations cited... it is clear that it did become at times a matter of style or emphasis" (Mitchell 1985: 616).

The variation Mitchell refers to is the fact that sometimes both split and unsplit coordinate constructions in Old English seem capable of expressing emphasis. Emphasis on an element would be - thus - sometimes achieved by either detaching it from phrasal coordination and placing it to the right of the sentence ( 7 a below), while at other times the cohesive status of phrasal coordinated structures would ensure emphasis on whatever elements stood within it (splitting them would then weaken the force) (7b):

7a) Soðlice seo cwen Triphonia gesohte ðæs halgan sacerdes fet Iustines mid biterum tearum, biddende pæs halgan fullhtes, and hire dohtor Cyrilla samod,

(AECHom i 434: 18).

b) Papa pæs caseres ðegnas gehyrdon pæt seo cwen Triphonia and Decius dohtor Cyrilla to Cristes geleafan and to ðam halwendum fulluhte gebogene wæron, hi ða mid heora wifum gesohton ðone halgan sacerd, and

11 I have analysed different variables to account for their presence or absence, but it does not seem to respond to any systematic condition or restriction. 
bædon miltsunge and fulluhtes.

(ACCHom i 434: 23). ${ }^{12}$

According to Mitchell (1985: 616), the fact that each woman wished to be converted in $7 \mathrm{a}$ is emphasized by the separation of the two nominative groups, but in (7b) the now-known fact of the conversion of both women is emphasized, and therefore both subjects come together under the same coordinated NP.

Reszkiewicz's (1966) conclusion that split coordination in Old English does not involve emphasis is not very convincing, as his argument is derived only from a comparison between Old English translations and their Latin originals. In fact, his statement that Old English split coordination examples "... render the Latin original... with no emphasis on the second part of the compound subject at all" (Reszkiewicz 1966: 314) is not really supported by data, as the Old English translations in the examples he quotes present a clearly different word order from that of the Latin originals:

8a) ... ibi sepultus est ipse et Sara uxor ejus

... ðær he ys bebirged and Sarra his wif

(Genesis $x x x)$.

b) Diligo dominum meum et uxores ac liberos.

Me is min hlaford leof and min wif and mine wenclo.

(Exodus xxi).

c) Egressus est Noe et omnes cum eo.

Noe ða ut eode of ðam arce and hie ealle ofer eorðan.

(Genesis viii). $^{13}$

It is true that it is very difficult to determine the communicative role of split coordination in Old English in the absence of any prosodic information. Sometimes it looks as though the choice between split or unsplit coordination was not determined by any grammatical or communicative factors, but was simply a decision made on the spur of the moment. ${ }^{14} \mathrm{I}$ think, however, that a close analy-

Examples from Mitchell (1985: 616).

Examples from Reszkiewicz (1966: 314-315).

14 The following example from the Anglo-Saxon Chronicle may illustrate this point: whereas MS C shows split coordination of the subject Tostig and his wif, the renderings of the same passage in MSS D and E present phrasal coordination:

i) \& Tostig for pa ofer sæ \& his wif mid him to Baldwines lande. 'and Tostig then went overseas with his wife to the land of Baldwin'

ii) \& Tostig Eorl \& his wif... faran suð ofer sæ to Baldwine eorle (ChronC 192.1065).

(ChronD 193.1065). 
sis of the textual material will provide some interesting clues.

In what follows I will try to prove that - in general terms - split coordination in Old English did not essentially have a highlighting or focusing function. On the contrary, I have found out that very often the split elements were relegated to a later position in the sentence because they were regarded as communicatively "less important" or because - if put together with the first element in the coordination - they would delay the presentation of important information in discourse. In addition to this, I hope I will be able to prove that - in general - subjects received more communicative attention in Old English if placed within phrasal conjunction than by splitting them. I have found conclusive evidence from three different sides of the phenomenon under discussion: the semantics of the elements involved in split coordination, the possibility of establishing internal subdivisions/groupings within coordinate split structures, and the difficult coexistence of phrasal coordinate subjects with topicalised NP objects in the same clause.

- The semantics of coordinate split subjects: A status hierarchy

In a very large number of instances of splitting of the subject in the corpus (71.1\%) we can observe a precedence hierarchy in the presentation of the participants in the action. ${ }^{15}$ This hierarchy is based on social status, reflecting the current world picture and social structure of Anglo-Saxon life: when expressing an action involving different coordinate subjects, the socially more important persons (the ones with the higher status, and often the central ones in the narration) are usually placed first in the sentence, and those participants with a lower status (and often with a less important role in the narration) are usually split and placed towards the right of the sentence (see 9a-d and Table 4 below):

9a) ...\& ferde se cyng him ham $\&$ pa ealdormen $\&$ pa heahwitan

'.. and the king, the ealdormen, and the chief councillors went home'

(ChronE 1009.139).

b) 1002 Her on pissum geare se cyng gerædde \& his witan pæt man sceolde gafol gyldan pam flotan.

' 1002 . In this year the king and his councillors decided to pay tribute to the fleet'

(ChronE 1002.133).

iii) \& Tostig eorl \& his wif... foron suð ofer sæ mid him to Baldwine eorle

(ChronE 192.1065).

15 These are, for the greater part, human or animate, this being a typical characteristic of subjecthood. $86.6 \%$ of the coordinate split subjects in the corpus are human or animate. 
c) ... and hu se papa Agatho hit feostnode mid his write \& se ærcb. Deusdedit.

'.. and how pope Agatho had confirmed it with his bull, and archbishop Deusdedit also'

(ChronE 963.116).

d) Se hcelend wæs eac gelapod to pam giftum and his leorningcnihtas samod. 'The Saviour was also invited to enjoy those gifts, and his disciples also'

(AECHom ii 29.5).

Table 4. Incidence of split subjects in which the split part is a lower-status participant

\begin{tabular}{lccc}
\hline & $\begin{array}{c}\text { Total split S } \\
\text { instances }\end{array}$ & $\begin{array}{c}\text { Social } \\
\text { ranking involved }\end{array}$ & $\begin{array}{c}\text { \% ranking } \\
\text { involved }\end{array}$ \\
\hline CP & 0 & - & - \\
Or & 17 & 12 & 70.5 \\
Boeth & 9 & 3 & 33.3 \\
Bede & 6 & 3 & 50 \\
ChronA,E & 65 & 52 & 80 \\
AELS (I) & 23 & 16 & 69.5 \\
AECHom ii & 19 & 12 & 63.1 \\
WHom & 3 & 2 & 66.6 \\
Total & 142 & 101 & 71.1 \\
\hline
\end{tabular}

Some of the most frequent precedence structures in coordinate split subjects in the corpus are:

10) Papa $>$ arcebiscop $>$ biscop $>$ abbod $>$ preost $>$ munuc $>$ nun.

Cyning $>$ ealdorman $/$ witan $>$ eorlas $>$ pegen $>$ holdas.

Crist, drihten, hælend $>$ englas $>$ leorningenihtas / apostoli.

Hlaford $>$ peowas $>$ men

To these we may add the more general and pervasive:

11) male $>$ female; husband $>$ wife; father $>$ son / daughter,

See examples 8a-b above and 12 below for illustration:

12a) ðu ælmihtiga god, pe abraham on belyfde and his sunu isaac, and eac swilce Iacob, geswutela on pysum dæge ... 
'Thou, God almighty, in whom Abraham believed, and his son Isaac, and also Jacob, manifest this day ...'

(AELS 1.390.127).

b) ...\& him pær an giong cyning mid firde ongean for, \& his modor mid him Damaris.

' $\ldots$ and a young king went against him with an army, together with his mother, Thamyris'

(Or 44.18).

c) Manege eac opre hrepene godas wæron mistlice fundende \& eac swylce hrepene gydena on swyplicum wyrpmente geond middaneard mancynne to forwyrde.

'Many other heathen gods and also heathen goddesses hastened variously to the destruction of mankind'

(WHom 224.81).

This arrangement of the coordinate subjects is also observable when the coordination consists of a long list of participants. In those cases, the most important one is usually introduced first and the rest appear at the end of the sentence, often closely following the aforementioned hierarchy based on social status:

13) Eac he lett gewritan hu mycel landes his arcebs. hæfdon \& his leod bs. \& his abbs. \& his eorlas ...

'He also had it recorded how much land his archbishops had, and his diocesan bishops, his abbotts and his earls ...'

(ChronE 1085.216).

In addition to this, in a fairly high number of examples of split coordination in the corpus the split element is an underspecified nominal expression such as $\&$ (ealle) poet folc, manige (oðer) (folc), \& micel folc, \& pa men, \& monige men, \& fela manna, \& his geferan, \& his men, etc., which adds to the argument that the postponed conjunt is regarded as "accessory" or "less important information".

14a) 838 Her Herebryht aldormon wæs ofslagen from hæpnum monnum, \& monige mid him on Merscwarum,

'838. In this year ealdorman Hereberht was slain by the heathen and many with him among the people of Romney Marsh'

(ChronA 838.62).

b) ...\& he pær wearp ofslagen \& poet folc mid him, 
'... and he was killed there and many people with him'

(Or 77.2).

c) Her Mul wearp on Cent forbærned, and opre xii men mid him.

'In this year Mul was burned to death in Kent and twelve other men with him'

(ChronA 687.38).

Therefore, if we assume that splitting somehow de-focuses some part of the coordination that Old English speakers considered less relevant, are we also to assume that focus or foregrounding of the elements belonging to the coordinate subject is achieved by letting them stay within the phrasal structures? I think so, and this is proven by the fact that all kinds of participants (i.e. persons of either equal $15 \mathrm{a}-\mathrm{b}$ or of different social status $15 \mathrm{c}-\mathrm{e}$ ) may appear in unsplit coordinate subjects, as long as the writer/compiler considered they had participated - rather "collaborated" - in equal terms in the fulfilment of a goal:

15a) 1063 Her for Harold eorl \& his broðor Tostig eorl ægðer ge mid land fyrde ge wið scip here into Brytlande.

'1063. In this year earl Harold and his brother earl Tostig invaded Wales both with land and naval levies'

(ChronE 1063.190).

b) 455. Her Hengest and Horsa fuhton wip wyrtgeorne pam cyninge ...

'455. In this year Hengest and Horse fought agaist king Vortigern ...'

(ChronA 449.12)

c) ...\& se cyng \& se eorl mid ormatre fyrde besæton pone castel abuton.

'... and with vast levies the king and the earl besieged the castle'

(ChronE 1090.225).

d) \& Gospatric eorl \& pa betstan menn foron into Scotlonde. 'and earl Gospatrci and the best men went into Scotland'

(ChronD 1067.202).

e) Gif moyses and ealle witegan witogoden pæt crist sceolde ðurh nearunysse his ðrowunge into his heofonlican wuldre faran ...

'If Moses and all the prophets had prophesied that Christ would go to his heavenly glory through the distress of his passion'

(AECHom ii 162.58).

Example 16 below, in which we have split and unsplit coordination in the 
same sentence, is quite interesting and somehow illustrates and summarises the points discussed so far:

16) Min broðor Peada \& min leoue freond Oswi ongunnen an mynstre Criste to loue \& Sancte Petre.

'My brother Peada and my dear friend Oswy began a monastery to the glory of Christ and St. Peter'

(ChronE 656.29).

The two monks Peada and Oswi - who we assume worked closely together in the founding of the monastery - appear in the unsplit coordinate structure to the left of the verb, but Christ is not placed side by side with Saint Peter in the formulaic expression Criste, Gode... to lofe.

- Internal subdivision/groupings within the coordinate structure

If - as we are suggesting - letting two or more NP subjects stay within phrasal coordination is a way of emphasising the coordinate structure as a whole, and subsequently each of its coordinate elements, then we should expect that internal subdivisions or groupings would arise within complex coordinate structures consisting of several NP subjects. This would allow the more important elements, now grouped into sets of two, three or more according to their inherent relevance, to stay within the phrasal structures to the left of the sentence, relegating the less important ones to the split portion. This is what happens in examples like 17 below:

17a) pa wærð martianus and eac seo modor dreorige on mode and heora men ealle.

'Then was Martianus, and also Celsus' mother sorrowful in mind, and all their men'

(AELS 1.102.195).

b) \& Rodbert arcb. \& Vlf b. gewendon ut æt Æstgeate \& heora geferan \& ofslogon \& elles amyrdon manige iunge men.

'and archbishop Robert and bishop Ulf and their companions went out by the East Gate and slew and otherwise injured many young men'

(ChronE 1052.181).

c) Đa com Godwine eorl \& Swegen eorl \& Harold eorl togædere æt Byferes stan \& manig mann mid heom.

'Then earl Godwin, earl Swein, and earl Harold met at Beverstone, and 
many men with them'

(ChronE 1048.174).

- Co-occurrence of coordinate unsplit subjects with topicalised objects

The final piece of evidence I would like to bring up in support of my claim that coordinate unsplit subjects in Old English are communicatively strong, marked units, with some inherent focality is somewhat indirect and comes from an analysis of the syntactic patterns in which coordinate unsplit subjects appear in the corpus. Let's examine Table 5:

Table 5. Unsplit coordinate subjects in different syntactic patterns in the corpus $^{16}$

\begin{tabular}{lcccccccc}
\hline & $\mathrm{S}^{\mathrm{n}} \mathrm{V}$ & $\mathrm{S}^{\mathrm{n}} \mathrm{VO}$ & $\mathrm{XS}^{\mathrm{n}} \mathrm{VO}$ & $\mathrm{S}^{\mathrm{n}} \mathrm{OV}$ & $(\mathrm{x}) \mathrm{VS}^{\mathrm{n}} \mathrm{O}$ & $\mathrm{OVS}^{\mathrm{n} *}$ & $\mathrm{OS}^{\mathrm{n}} \mathrm{V}^{*}$ & $(\mathrm{x}) \mathrm{VS}^{\mathrm{n}}$ \\
\hline Bede & 6 & 18 & 14 & 36 & 9 & 1 & 4 & 29 \\
Boeth & 4 & 55 & 3 & 22 & 2 & - & 2 & 27 \\
Or & 4 & 29 & 12 & 11 & 4 & - & 2 & 16 \\
CP & 1 & 26 & 2 & 6 & 1 & 1 & 1 & 19 \\
Chron (A, E) & 14 & 37 & 71 & 16 & 30 & 2 & 2 & 67 \\
AES (vol. 1) & 0 & 18 & 1 & 13 & 19 & - & - & 22 \\
ECHom ii & 0 & 41 & 3 & 11 & 15 & 1 & - & 40 \\
WHom & 0 & 9 & 1 & 5 & 16 & - & - & 29 \\
\hline Total & 29 & 233 & 107 & 120 & 96 & 5 & 11 & 249 \\
\hline
\end{tabular}

As we can see, in the vast majority of the examples of unsplit subject coordination in the corpus, subjects precede objects. What I find revealing is the fact that, whereas in sentences with single, non-coordinate subjects, topicalisation of NP objects - with or without subject inversion - was very common in Old English, the incidence of topicalised objects in sentences with complex, coordinate subjects is very low (only 16 instances in the whole corpus). ${ }^{17}$

16 "S" stands for subject, "O" for direct object, "V" for verbal nucleus and "X" for PP's and adverbials.

* Excluding those instances where the object is a relative pronoun, or a topicalised pronoun the object of a preposition.

17 See Haeberli (2001) for a very interesting and up-to-date discussion on the conditions that govern subject-verb inversion after topicalisation of the object.

Out of the 16 examples of topicalised objects followed by complex NP subjects in the corpus (in either OVS or OSV structures), 11 are pronominal and only 4 are fully nominal. See (i.) and (ii.) below for illustration of both:

Đas writ seonde seo papa Agatho \& an hundred \& fif \& twenti biscopes bi Wilfried ærcebis- 
In my opinion, the explanation might lie in the fact that the Old English language disallowed a structure with too many focal elements at a time. Topicalised NP objects (in either $\mathrm{OVS}^{\mathrm{n}}$ or $\mathrm{OS}^{\mathrm{n}} \mathrm{V}$ structures) are focal due to their syntactic position, and on the other hand, coordinate subjects are inherently focal due to their complexity. Complex subjects appear in the corpus, thus, in those positions in which no information structure conflicts arise, i.e., initial and final position in the clause (the former, the typical position for both foci and unmarked topics, the latter the one in which end-weight predicts long subjects will land). We can also find complex subjects in medial position preceded by PP's and adverbial adjuncts and post-verbally after the application of the V2nd rule, but they do not normally co-occur with topicalised objects.

From what has been said so far I think we can conclude that split coordination in Old English does not essentially depend on the syntactic size of the coordinate subjects, nor does it have a primarily highlighting function on the split element. The only option left, then, is to consider split subjects as "afterthoughts". However, given that the notion "afterthought" is somewhat loose and open to different interpretations, I think a little comment on its implications is in order.

\subsubsection{Afterthought}

The abstract definition of "afterthought" quoted at the beginning of this section (i.e. "late additions in the process of production of an utterance, which were not in the original plan") is valid to explain some modern English facts, but I do not think it really holds for most instances of split coordination in Old English.

Many of the examples of split subjects in the corpus are very short sentences, like 1a and $3 \mathrm{c}$ above - repeated here as for convenience as $18 \mathrm{a}$ and $18 \mathrm{~b}$ :

18a) Her Beorhtric cyning forpferde \& Worr aldormon.

'In this year king Beorhtric passed away, and ealdorman Worr'

(ChronA 800.58).

b) Đrihten pa astah into pam scipe \& petrus samod.

'Our lord then ascended into the ship, and Peter too'

(AECHom ii 223.77).

cop of Eoferwic to Engla lande.

'Pope Agatho and a hundred and twenty-five bishops sent this bull to England by archbishop Wilfrid of York'

(ChronE 675.37).

...forðæm under his forgiefnesse hine gefrieðode sie lufu \& se geleafa \& se tohopa.

'...because under his forgiveness love, faith, and hope protected him'

(CP 167.24). 
so I seriously doubt that real-time constraints in producing these utterances (i.e. short-time memory limitations) should have really caused the "on line" insertion of the second subject. On the contrary, I think that in the process of conceptualising the message speakers may have had both subjects in store, but the pragmatic restrictions that prevent the co-occurrence under the same coordinated node of two pragmatically incompatible units (in this case participants from very different social status) caused the postposition of the second. This way, the postposition of the second subjects in split coordinated structures could be seen as an indirect way of actually highlighting the first. So, in the end split coordination "might be" a mechanism of focus assignment, but not - as expected - on the split part, but on the one that remains to the left of the sentence. This way, split coordination would respond to Givon's $(1983,1988)$ Task Urgency Principle, which states that important precedes unimportant information, or that information that is communicatively urgent precedes that which is less so. In example (18a) above, for instance, the most urgent task would be expressing the death of king Beorhtric. Placing nobleman Worr in the same coordinate subject would prevent a quick closing of the subject-predicate chain, delaying the presentation of what the speaker considered important information. Not unsurprisingly, then, the highest proportion of split subjects in the corpus appears in narrative and annalistic texts (in which different actions involving many different characters are presented in fast succession), a suitable context for the use of such mechanisms of discourse organisation. Therefore, the characteristics of the genre or authorship of an Old English text may be determinant factors in the incidence of split coordination, which - as pointed out before - seriously challenges the view that split coordination is a grammatically motivated process.

\subsection{Position of the split elements}

In most of the analyses I am familiar with (with the exception of Reszkiewicz 1966) only examples in which the split elements appear in absolute clause-final position are discussed. ${ }^{18}$ However, a close examination of the corpus data re-

18 In two recent works on Old English syntax Traugott (1992: 281) and Davis (1997: 59) examples of split subjects with the split portion in medial position in the clause are quoted, but not discussed:

God bebead Abrahame pæt he sceolde and his offspring his wed healdan.

(AECHom I, 92.30).

His apostoli arærdon and heora æftergengan manega menn of deap.

(Ælfric SH vi. 324).

Other studies like Sasao (1981) and Sielanko (1995), in which the clause-final status of split elements is crucial to their argumentation, systematically overlook the fact that split elements 
veals that split subjects can appear in a variety of positions in the sentence, to the right of the verbal nucleus:

Table 10. Percentage of split subjects in which the split element appears in non clause-final position

\begin{tabular}{lccc}
\hline & Total split subjects & Non-final position & $\begin{array}{c}\text { \% non-final } \\
\text { position }\end{array}$ \\
\hline CP & 0 & - & - \\
Or & 17 & 1 & 5.8 \\
Boeth & 9 & 0 & 0 \\
Bede & 6 & 1 & 16.6 \\
Chron (MS A,E) & 65 & 7 & 10.7 \\
ELS (I) & 23 & 11 & 47.8 \\
AECHom ii & 19 & 4 & 21 \\
WHom & 3 & 2 & 66.6 \\
\hline Total & 155 & 26 & 16.7 \\
\hline
\end{tabular}

Specifically, in 14 out of the 26 relevant examples, split subjects appear between complements and adjuncts:

19a) 755 Her Cynewulf benam Sigebryht his rices and westseaxna wiotan for unryhtum dædum, buton Hamtunscire.

'755. In this year Cynewulf and the councillors of Wessex deprived Sigeberht of his kingdom for unlawful actions, except Hampshire'

(ChronA 755.46).

b) Lacedom is alyfed fram lichamena tyddernysse \& halige gebedu mid godes bletsunge.

'Medicine is granted for bodily infirmity, and holy prayers, with God's blessing'

(AELS 1.378.213).

c) ac foxunga wæron wunigende on him and up-ahefednys swilce healice fugelas

'but foxlike wiles were dwelling in him and haughtiness, like unto soaring birds'

(AELS 1.348.162)

may appear in non-clause-final position. 
and in more or less the same proportion (12 out of the 26 relevant examples) the split element is inserted between the verbal nucleus and some of its complements, causing discontinuity within the verbal complex (see $9 \mathrm{~b}$ above and the examples below):

20a) Maurus ba ferde mid mycelre blisse and his geferan samod to francena rice. 'Then Maurus fared with great joy, and his companins together to the kingdom of the Franks'

(AELS 1.152.90).

b) ...\& sona pær æfter sende se cyng him \& se arceb. of Cantwarbyrig to Rome æfter pæs ærceb. Pallium.

'... and soon afterwards the king and the archbishop of Canterbury sent him to Rome for the archbishop's pallium'

(ChronE 1114.246).

c) ... pæt he scolde \& his cynn gefyllan on heofonum pæt se deofol forworhte purh his ofermodignesse.

'... that he and his family should repair in heaven what the devil had performed through his arrogance'

(WHom. 145.41).

d) ... pæt heora ærende wæs \& heora siðfæt from Drihtne seolfum gehradod \& gesyndgad.

'.. that their errand and their journey were promoted and prospered by the lord himself'

(Bede 320.11).

So far I could not say what the implications of this are. If we consider the possibility that split elements were treated as appositions or parentheticals (which would be in line with the "afterthought" vision I have drawn some lines before) then any claims about the effects of split coordination on constituency and structure would have to be questioned. Otherwise, the discontinuity caused by split coordination would constitute a serious challenge to the hypothesis that Old English is a strictly configurational language and that its VP has a complex, binarybranching structure. This is, once more, very difficult to assess in the absence of prosodic information, or - since we are dealing with texts - a more informative punctuation system. In any case, I think the incidence of this fact and its distribution in the corpus is significant enough as to deserve further and deeper investigation, and is, in my opinion, an interesting path of future research. 


\section{Summary and conclusions}

The conclusions to which I have come in this paper constitute a challenge to some of the received wisdom on split coordination in Old English, and can be summarised in the following points:

a. Split coordination is highly conditioned by style. The widely diverging patterns for its incidence in the different works in the corpus suggest that it is not a strictly syntactic, grammatically-motivated process and that its application depended to a great extent on other factors, including communicative and discoursive ones. At least as far as subjects are concerned, split coordination is certainly not triggered by the conditions on the structural size of constituents, as the statistical data show that light coordinate subjects very often become split and - conversely - sometimes very long and complex ones tend to remain unsplit. Discourse saliency and the semantics of the elements involved in coordination have a much greater bearing on the application of the rule than size itself.

In this respect, I have found out that split coordination of the subject was used quite consistently as a foregrounding device, allowing a hierarchical organisation of the relevant elements in communication (the more important to the left of the sentence, the less important to the right). This is clearly shown by the distribution and relative incidence of the phenomenon in the different text types in the corpus: in annalistic and narrative texts, in which a clear temporal sequencing and specification of the participants in the action is needed, the incidence of split subjects was much higher than in rest of the works.

b. Split elements appear in non clause-final position much more often than has been assumed, producing discontinuous constituents. This fact constitutes a serious problem for any approach to Old English word order that relies heavily on strict conditions of configurationality. Therefore, this aspect of Old English syntax deserves greater attention than has traditionally been paid to, and a detailed analysis which - among other proposals - takes into account the possibility of considering split elements as appositive ones.

\section{REFERENCES}

\section{PRIMARY SOURCES}

Bately, Janet (ed.)

1980 The Old English Orosius. (EETS, Supplementary Series Vol. 6). London: Oxford 
University Press.

Bethurum, Dorothy (ed.)

1975 The homilies of Wulfstan. Oxford: Clarendon Press.

Fox, Samuel (ed.)

1864 King Alfred's Anglo-Saxon version of Boethius. 'De Consolatione Philosophiae'. London: G. Bell.

[1970] [Reprint. New York: AMS Press].

Godden, Malcom (ed.)

1979 Alfric's catholic homilies. The second series. (Early English Text Society, Supplementary Series Vol. 5). London: Oxford University Press.

Miller, Thomas (ed.)

1890-1898The Old English version of Bede's 'Ecclesiastical history of the English people'. (EETS, OS 95, 96, 110, 111, 1988). London: N. Trübner.

[1978] [Reprint. Millwood - New York: Kraus].

Plummer, Charles (ed.)

1892 Two of the Saxon chronicles parallel: Based on an edition by John Earle. Oxford: Clarendon Press.

[1952] [Reprint].

Skeat, Walter W. (ed.)

1881-1900 Elfric's Lives of Saints. (2 vols) (EETS, OS 76, 82, 94, 114). London: N. Trübner.

[1966] [Reprint. London: Oxford University Press].

Sweet, Henry (ed.)

1871-1872King Alfred's West-Saxon version of Gregory's 'Pastoral Care'. (EETS, OS 45, 50). London: N. Trübner.

[1988] [Reprint. Millwood - New York: Kraus].

\section{SECONDARY SOURCES}

Anderson, John M. - Norman MacLeod (eds.)

1988 Edinburgh studies in the English language 1. Edinburgh: John Donald.

Arnold, Jennifer E. - Thomas Wasow - Anthony Losongco - Ryan Ginstrom

2000 "Heaviness vs. newness: The effects of structural complexity and discourse status on constituent ordering", Language 17/1: 28-55.

Behaghel, Otto

1909 "Beziehungen zwischen Umfang und Reihenfolge von Satzgliedern", Indogermanische Forschungen 25: 110-142.

Brahmer, Mieczysław - Stanisław Helsztyński - Julian Krzyżanowski (eds.)

1966 Studies in language and literature in honour of Margaret Schlauch. Warszawa: Państwowe Wydawnictwo Naukowe.

Canale, William Michael

1978 Word order change in Old English: Base reanalysis in generative grammar. [Unpublished Ph.D. dissertation, McGill University].

Chao, Wynn

1987 On ellipsis. [Ph.D. dissertation, University of Massachusetts Amherst - Published by Graduate Linguistics Students Association, Umass, Amherst]. 
Colman, Fran

1988 "Heavy arguments in Old English", in: John M. Anderson - Norman MacLeod (eds.), 33-89.

Davis, Graeme

1997 The word-order of AElfric. Lewiston - Queenston - Lampeter: The Edwin Mellen Press.

Fanego, Teresa (ed.)

1993 Papers from the $4^{\text {th }}$ International Conference of the Spanish Society for Medieval English Language and Literature. Santiago de Compostela: Universidade de Santiago.

Ferreira, Fernanda

1991 "Effects of length and syntactic complexity on initiation times for prepared utterances", Journal of Memory and Language 30/2: 2110-2233.

Fischer, Olga - Ans van Kemenade - Willem Koopman - Wim van der Wurff (eds.)

2000 The syntax of Early English. Cambridge: Cambridge University Press.

Givon, Talmy (ed.)

1983 Topic continuity in discourse: A quantitative cross-language study. Amsterdam: John Benjamins.

Givon, Talmy

1988 "The pragmatics of word order: Predictability, importantce and attention", in: Michael Hammond - E. A. Moravcsik - Jessica Wirth (eds.), 192-200.

Goodall, Grant

1987 Parallel structures in syntax. Cambridge: Cambridge University Press.

Haeberli, Eric

2001 "Speculations on the syntax of subordinate clauses in Old English", Reading Working Papers in Linguistics 5: 201-229.

Hammond, Michael - E. A. Moravcsik - Jessica Wirth (eds.)

1988 Studies in syntactic typology. (Typological Studies in Language 17). Amsterdam: John Benjamins.

Hankamer, Jorge

1979 Deletion in coordinate structures. New York - London: Garland.

Hankamer, Jorge - Ivan Anthony Sag

1976 "Deep and surface anaphora", Linguistic Inquiry 7: 325-345.

Hawkins, John A.

1990 “A parsing theory of word order universals", Linguistic Inquiry 21/2: 223-261.

Hawkins, John A.

1994 A performance theory of order and constituency. Cambridge: Cambridge University Press.

Hogg, Richard M. (ed.)

1992 The Cambridge history of the English language. Vol. 1: The beginnings to 1066. Cambridge: Cambridge University Press.

Jackendoff, Ray

1971 "Gapping and related rules", Linguisitc Inquiry 2/1: 21-36.

Johannessen, Janne Bondi

1998 Coordination. New York - Oxford: Oxford University Press.

Kohonen, Viljo

1978 On the development of English word order in religious prose around 1000 and 1200 
Li, Charles N. (ed.)

A.D. Åbo: Åbo Akademi Foundation.

1977 Mechanisms of syntactic change. Austin - London: University of Texas Press. Lobeck, Anne C.

1995 Ellipsis: Functional heads, licensing and identification. New York - Oxford: Oxford University Press.

Mitchell, Bruce

1985 Old English syntax (2 vols). Oxford: Clarendon Press.

Mitchell, Bruce - Fred C. Robinson

1986 [1964] A guide to Old English. Oxford: Blackwell.

Mondorf, Britta

2003 "Support for more-support", in: Günther Rohdenburg - Britta Mondorf (eds.), 251304.

Pérez Lorido, Rodrigo

1993 "A typological description of coordinate construction in Ælfric's Lives of Saints", in: Teresa Fanego (ed.), 241-257.

Pérez Lorido, Rodrigo

1996 "On the grammatical domain of gapping in Old English: Syntax and pragmatics", Diachronica 13/2: 319-346.

Pintzuck, Susan - Anthony S. Kroch

1989 "The rightward movement of complements and adjuncts in the Old English of Beowulf", Language Variation and Change 1: 115-143.

Reszkiewicz, Alfred

1966 "Split constructions in Old English", in: Brahmer, Mieczysław - Stanisław Helsztyński - Julian Krzyżanowski (eds.), 313-326.

Rickford, John R. - Norma Mendoza-Denton - Thomas Wasow - Julie Espinoza

1995 "Syntactic variation and change in progress: Loss of the verbal coda in topicrestricting as far as constructions", Language 71/1: 102-131.

Rohdenburg, Günther - Britta Mondorf (eds.)

2003 Determinants of grammatical variation in English. Berlin - New York: Mouton de Gruyter.

Sag, Ivan Anthony

1980 Deletion and logical form. New York - London: Garland.

Sasao, Kazuyo

1981 "A deletion analysis of Old English split constructions", Descriptive and Applied Linguistics 15: 187-198.

Sielanko, Elżbieta

1995 "Split coordinated structures in late Old English", Studia Anglica Posnaniensia 29: 57-72.

Stockwell, Robert

1977 "Motivations for exbraciation in Old English", in: Charles N. Li (ed.), 291-314.

Taylor, Ann - Anthony Warner - Susan Pintzuk - Frank Beths

2003 The York-Toronto-Helsinki parsed corpus of Old English. Department of Language and Lingusitic Science, Universiy of York. (Available through the Oxford Text Archive).

Traugott, Elizabeth Closs

1972 A history of English syntax. New York: Holt - Reinhart \& Winston. 
Traugott, Elizabeth Closs

1992 "Syntax", in Richard M. Hogg (ed.), 168-289.

Van Hoorick, Bart

1994 Pragmatic positions and the history of English word order: A functional grammar perspective. (Working papers in functional grammar 56). Amsterdam: University of Amsterdam.

Van Kemenade, Ans

1987 Syntactic case and morphological case in the history of English. Dordrecht: Foris.

Van Kemenade, Ans - Bettelou Los

2006a "Discourse adverbs and clausal syntax in Old and Middle English", in: Ans van Kemenade - Bettelou Los (eds.), 224-248.

2006b The handbook of the history of English. Oxford: Blackwell.

Van Oirsouw, Robert R.

1987 The syntax of coordination. London - New York - Sydney: Croom Helm.

Wasow, Thomas

1997 "Remarks on grammatical weight", Language Variation and Change 9: 81-105. 